\title{
Dermatoglyphs in carriers of a balanced 15;21 translocation
}

\author{
A RODEWALD, M ZANKL, H ZANKL, AND K D ZANG \\ From the Institute of Human Genetics, University of Saarland, $6650 \mathrm{Homburg} /$ Saar, \\ Federal Republic of Western Germany
}

SUMMARY Cytogenetic and dermatoglyphic features were studied in a large family with an inherited $15 ; 21$ translocation. Of 35 healthy members of the family, 21 carried the translocation chromosome and 14 were chromosomally normal. There were six members with Down's syndrome who had the translocation. Dermatoglyphic studies showed that carriers of this balanced translocation had the following peculiarities significantly more often than the general population. On the hands, they had ulnar loops on the fingertips, symmetrical high terminations of the A line, symmetrical ulnar loops on the hypothenar areas, distal loops in the 3rd interdigital areas, open fields in the 4th interdigital areas, axial triradii in the distal position, and single transverse palmar creases (Sydney lines). On the feet, they had small distal loops on the hallucal area and distal loops in the 4th interdigital areas.

The translocation carriers also had significantly more often than non-carrier relatives symmetrical high terminations of the A line, open fields in the 4th interdigital areas, distal axial triradii, and Sydney lines. On the feet, they had small distal loops on the hallucal areas, distal loops in the 4th interdigital areas, and tibial loops on the proximal hypothenar areas. The data obtained from this study, and especially the values of the Walker and general indices, indicate that some of the dermatoglyphic stigmata of Down's syndrome are directly associated with the $15 ; 21$ translocation carrier state and can therefore be used for predicting that state.

Several diagnostic indices based on the relative frequencies of various dermatoglyphic patterns on the fingertips, palms, and soles have been proposed for the dermatoglyphic diagnosis of Down's syndrome. ${ }^{1-9}$ The dermatoglyphs in translocation types of Down's syndrome were found to resemble closely those in free trisomy cases. ${ }^{10-12}$ However, the dermatoglyphic data in phenotypically normal carriers of balanced 13-15;21 translocations have been conflicting.

We have tried to clarify this question by making a detailed description of all the dermatoglyphic features on the fingertips, palms, and soles in a large family with an inherited 15;21 translocation.

\section{Cytogenetic and dermatoglyphic findings}

We studied the cytogenetic and dermatoglyphic data for a large family spread over four generations, in which six members had features of Down's syndrome

Received for publication 16 October 1979 and 21 phenotypically normal members had the same $15 ; 21$ translocation with a chromosome count of 45 . Normal karyotypes were found in 14 other phenotypically normal close relatives. The pedigree data are given in fig 1. The dermatoglyphic findings in this family are compared with those in 150 patients with free trisomy 21 and in a control series of 552 phenotypically and chromosomally normal persons from southern Germany. The statistical evaluation of the general index included 30 features of the palms and soles (Walker index $=16$ ) as described earlier. ${ }^{89}$

FINGERTIP PATTERNS (TABLE 1)

The translocation carriers had similar relative frequencies of the various fingertip patterns to the controls and the normal relatives. However, there was a high frequency of ulnar loops on the right 2 nd finger $(43 \%$, compared to $33.3 \%$ in the controls and $21.4 \%$ in the normal relatives) and of radial loops on both 4 th fingers $(4.8,0 \cdot 2$, and $0 \%$, respectively), and a decrease of radial loops on the 2 nd fingers 


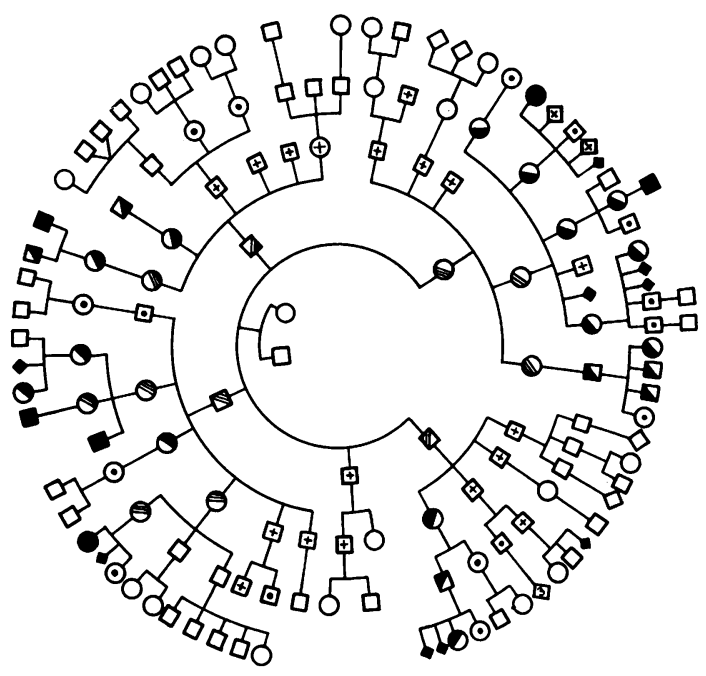

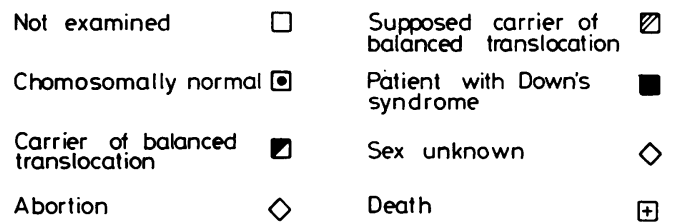

FIG 1 Pedigree of family with inherited 15;21 translocation.

TABLE 1a Fingertip patterns (\%) in trisomy 21 patients, carriers of balanced 15;21 translocation, their normal relatives, and normal controls

\begin{tabular}{lllll}
\hline $\begin{array}{l}\text { Fingertip } \\
\text { patterns }\end{array}$ & $\begin{array}{l}\text { Trisomy 21 } \\
(n=1500)\end{array}$ & $\begin{array}{l}t(15 ; 21) \\
(n=210)\end{array}$ & $\begin{array}{l}\text { Normal } \\
\text { relatives } \\
(n=140)\end{array}$ & $\begin{array}{l}\text { Controls } \\
(n=5520)\end{array}$ \\
\hline $\begin{array}{l}\text { Whorls (W) } \\
\text { Ulnar loops } \\
\text { (U) }\end{array}$ & 16.1 & 35.7 & 28.6 & 30.7 \\
$\begin{array}{c}\text { Radial loops } \\
\text { (R) }\end{array}$ & 2.8 & 58.6 & 65.0 & 58.6 \\
Arches (A) & 1.5 & 3.8 & 4.3 & 4.5 \\
\hline
\end{tabular}

TABLE $1 \mathrm{~b}$ Fingertip patterns (\%) on the 2nd and 4th fingers in trisomy 21 patients, carriers of balanced 15;21 translocation, their normal relatives, and normal controls

\begin{tabular}{lrrrr}
\hline $\begin{array}{l}\text { Fingertip } \\
\text { patterns }\end{array}$ & Trisomy 21 & $t(15 ; 21)$ & $\begin{array}{l}\text { Normal } \\
\text { relatives }\end{array}$ & Controls \\
\hline U, 2nd finger 91.0 & 43.0 & 21.4 & $33 \cdot 3$ \\
R, 4th finger 7.8 & 4.8 & 0.0 & 0.2 \\
R, 2nd finger & 0.5 & 4.8 & 21.4 & 20.5 \\
\hline
\end{tabular}

$(4 \cdot 8,20 \cdot 5$, and $20 \cdot 4 \%$ respectively). These differences were statistically significant $(\mathrm{p}<0 \cdot 05)$.

PALMAR PATTERNS (TABLES 2 AND 3)

Higher frequencies of right-left symmetry in the terminations of the main palmar lines were found in $\frac{\bar{c}}{\bar{c}}$ the translocation carriers than in the controls and $\vec{\nabla}$ normal relatives: the $A$ line in five, $(p<0.01$ and $\propto$ 0.05 , respectively); the $B$ line in seven $(p<0.05$ \% for both); the $\mathrm{C}$ line in nine $(\mathrm{p}<0.05$ for both); $\vec{O}$ and the $\mathrm{D}$ line in $11(\mathrm{p}<0.05$ for both).

The mean value of the combined right and left atd $\vec{\omega}$ angles of the translocation carriers $(90.18 \pm 23.91)$ ? was higher than in the non-carriers (74.07 $\pm 18 \cdot 81)$. The mean value for the control series was 88.07 $\pm \vec{\nu}$ 18.70. The surprisingly low mean value of the atd angle of the chromosomally normal family members $\omega$ was the result of a familial dislocation of the $a$ 오 triradii to the ulnar side, a trait that also appeared 음 in the translocation carriers. The high mean value of the atd angles in carriers of the balanced trans- $\geq$ location could be explained by the frequent occur- $\bar{c}$ rence of distally placed axial triradii $\mathrm{t}^{\prime \prime}$ which was $\stackrel{5}{?}$ found in $19.0 \%$ of the palms. The controls had $\vec{\bullet}$

TABLE 2 Frequency of right/left symmetry of main line terminations in trisomy 21 patients, carriers of balanced 15;21 translocation, their normal relatives, and normal controls (\%)

\begin{tabular}{|c|c|c|c|c|}
\hline Main lines & $\begin{array}{l}\text { Trisomy } 21 \\
(n=150)\end{array}$ & $\begin{array}{l}t(15 ; 21) \\
(n=21)\end{array}$ & $\begin{array}{l}\text { Normal } \\
\text { relatives } \\
(n=14)\end{array}$ & $\begin{array}{l}\text { Controls } \\
(n=552)\end{array}$ \\
\hline $\begin{array}{l}\text { A5'/A5' } \\
\text { B7/B7 } \\
\text { C9/C9 } \\
\text { D11/D11 }\end{array}$ & $\begin{array}{l}35 \cdot 3 \\
66 \cdot 0 \\
48 \cdot 0 \\
74 \cdot 0\end{array}$ & $\begin{array}{l}33 \cdot 3 \\
28 \cdot 6 \\
33 \cdot 3 \\
33 \cdot 3\end{array}$ & $\begin{array}{l}21 \cdot 4 \\
21 \cdot 4 \\
21 \cdot 4 \\
21 \cdot 4\end{array}$ & $\begin{array}{l}15 \cdot 8 \\
23 \cdot 7 \\
20 \cdot 5 \\
26 \cdot 6\end{array}$ \\
\hline
\end{tabular}

TABLE 3 Frequency (\%) of palmar patterns in trisomy 21 patients, carriers of balanced translocation, their normal relatives, and normal controls*

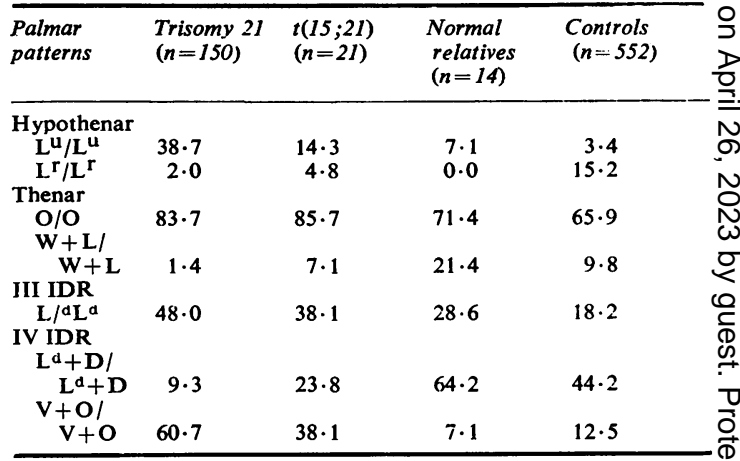

*Nomenclature from Penrose LS. Memorandum on dermatoglyphic $\varrho$ nomenclature. Birth Defects 1968;6:No 3. 
such $\mathrm{t}^{\prime \prime}$ triradii only in $8.5 \%$ and the normal relatives in $0 \%$. These differences were statistically significant $(\mathrm{p}<0 \cdot 05)$.

The incidence of symmetrical ulnar loops on the hypothenar area was significantly higher in the balanced carriers than in the controls $(p<0.001)$ or in the normal relatives $(p=0.05)$. The incidence of radial loops, however, was clearly decreased $(p<0.05)$. There were fewer true thenar patterns (loops and whorls) in the balanced carriers than in the controls $(p>0.05)$ or the normal relatives $(p<0.05)$, and a markedly higher frequency of symmetrical open fields $(\mathrm{p}<0.05)$.

The balanced carrier group had a much higher frequency of symmetrical distal loops in the 3rd interdigital areas than did the controls or the normal relatives (both $p=0.05$ ), and a significantly lower frequency of symmetrical true patterns in the 4th interdigital areas $(p<0.05$ for both). No family member showed a typical simian crease. The incidence of symmetrical atypical forms was clearly higher $(28.6 \%$ had a Sydney line and $14.3 \%$ an abortive form) in the balanced translocation carriers than in the controls $(0.4 \%$ had a Sydney line and $2.3 \%$ had abortive forms) or in the normal relatives $(0 \%)$. The differences were highly significant for both $(\mathrm{p}<0 \cdot 001)$.

\section{Plantar PATTERNS (TABLE 4)}

The hallux in the balanced carriers had a markedly higher frequency of symmetrical small distal loops $(<20)$ than that in the controls $(p<0.001)$ or the normal relatives $(p=0.05)$, and fewer symmetrical whorls ( $<<0.05$ for both). There were also higher frequencies of distal loops in the 4th interdigital area $(p<0.05)$, and of tibial loops on the distal hypothenar area $(\mathrm{p}<0.05)$.

\section{Discussion}

Some authors, such as Penrose and Delhanty, ${ }^{10}$

TABLE 4 Frequency (\%) of plantar patterns in trisomy 21 patients, carriers of balanced translocation, their normal relatives, and normal controls

\begin{tabular}{|c|c|c|c|c|}
\hline $\begin{array}{l}\text { Plantar } \\
\text { patterns }\end{array}$ & $\begin{array}{l}\text { Trisomy } 21 \\
(n=150)\end{array}$ & $\begin{array}{l}t(15 ; 2 I) \\
(n=2 I)\end{array}$ & $\begin{array}{l}\text { Normal } \\
\text { relatives } \\
(n=14)\end{array}$ & $\begin{array}{l}\text { Controis } \\
(n=552)\end{array}$ \\
\hline \multicolumn{5}{|l|}{ Hallux } \\
\hline $1 \mathrm{~d} / 1^{\mathrm{d}}$ & $37 \cdot 0$ & $28 \cdot 6$ & $7 \cdot 1$ & $3 \cdot 4$ \\
\hline $\mathbf{W} / \mathbf{W}$ & $3 \cdot 5$ & $4 \cdot 8$ & $14 \cdot 3$ & $19 \cdot 0$ \\
\hline \multicolumn{5}{|l|}{ II IDR } \\
\hline $0 / 0$ & $57 \cdot 0$ & $38 \cdot 1$ & $35 \cdot 7$ & $27 \cdot 2$ \\
\hline $\mathbf{L p} / \mathbf{L} \mathbf{p}$ & 7.0 & $9 \cdot 5$ & $14 \cdot 3$ & $12 \cdot 3$ \\
\hline \multicolumn{5}{|l|}{ IV IDR } \\
\hline $\mathbf{L}^{d} / L^{d}$ & 38.0 & $42 \cdot 9$ & $21 \cdot 4$ & $8 \cdot 2$ \\
\hline $\mathbf{O} / \mathbf{O}$ & 0.0 & $23 \cdot 8$ & $50 \cdot 0$ & $41 \cdot 5$ \\
\hline $\begin{array}{l}\text { Hypothenar } \\
\text { distal Lt/Lt }\end{array}$ & $58 \cdot 5$ & $71 \cdot 4$ & $28 \cdot 6$ & $38 \cdot 8$ \\
\hline
\end{tabular}

Walker et $a l,{ }^{13}$ and Fung and Zavatone, ${ }^{14}$ found in carriers of the balanced 13-15;21 translocation a combination of dermatoglyphic patterns quite similar to those in Down's syndrome. The combination included increased frequencies of ulnar loops on the fingertips, bilateral transverse single creases, distally placed axial triradii, high atd angle values, and large hypothenar patterns on the palms. Based on their results, Penrose and Delhanty ${ }^{10}$ postulated that "the major genetical determinants of the hypothenar patterns and height of the axial triradius are located on chromosome 21 and that the presence of an allele upon the fused $D / G$ chromosomes tends to centralize the triradius $t$ in distal position $t^{\prime}$ and/or $t^{\prime \prime}$." In contrast, Sergovich et al ${ }^{15}$ found no difference between the mean atd angles in eight carriers of balanced 13-15;21 translocations and 13 non-carrier relatives. However, these authors did not study any other dermatoglyphic patterns and furthermore it seems possible that they were studying a different type of translocation because the acrocentrics could not be identified by banding techniques.

In our material the following atypical dermatoglyphic patterns were found in the carriers of the balanced $15 ; 21$ translocation compared with the controls and the chromosomally normal relatives. On the hands, there were frequent ulnar loops and fewer radial loops on the 2nd finger; a greater frequency of radial loops on the 4th finger; more frequent symmetry of the $\mathrm{A}$ line ending in five, the $B$ line in seven, the $C$ line in nine, and the $D$ line in 11; and increased frequency of all the following: ulnar loops on the hypothenar area, open fields in the thenar area, distal loops in the 3rd interdigital area, rudimentary patterns (vestigial) in the 2 nd and 4th interdigital areas, distal axial triradii, Sydney lines, and abortive forms of simian creases. On the soles, there were small loops on the hallux; open fields in the 2nd and 3rd interdigital areas; distal loops in the 4th interdigital areas; and tibial loops in the hypothenar areas were increased. These combinations of dermatoglyphic patterns found in translocation carriers resembled those found in Down's syndrome. Great symmetry of the dermatoglyphic patterns on the right and left palms in patients with Down's syndrome has been reported. ${ }^{689}$ This strong tendency to bilateral symmetry of the patterns in Down's syndrome patients accounts for the statistical significance of differences from the balanced carrier group in the frequencies of fingertip patterns: B line termination in seven, $\mathrm{C}$ line termination in nine, $\mathrm{D}$ line termination in 11 , distal axial triradii, and distal loops in the 3rd and open fields in the 4th interdigital areas (all on the palms), and small loops on the hallux. No significant differences were found in the terminations of the $\mathrm{A}$ line or in the 
hypothenar pattern on the hands, or in the patterns of the 2nd and 4th interdigital areas and hypothenar areas on the feet. Generally, the group of balanced carriers was intermediate between the Down's syndrome patients and the controls with regard to the courses of the main lines and the patterning on the fingertips, palms, and soles.

The combination of a distally placed axial triradius and large hypothenar patterns was found bilaterally in ten and unilaterally in two of the 21 translocation carriers. An unusual finding was the high incidence of a single transverse crease (especially a Sydney line) on the palm (11 bilaterally and three unilaterally) and a small distal loop on the hallux (six bilaterally and three unilaterally). It is therefore interesting in this context to examine how often these dermatoglyphic peculiarities were combined in the same translocation carrier. Twelve carriers had a simian crease, distally placed axial triradius, and hypothenar pattern, but only three carriers had the combination of small distal loops on the hallux, a distal axial triradius, and hypothenar pattern.

The combination of dermatoglyphic patterns and the degree of the stigmata of Down's syndrome can be mathematically expressed by the 'Walker' and the 'general' indices. ${ }^{1289}$ The calculation of the Walker index values in the carriers showed seven values characteristic of the normal population (range -3 to -9 ) and 14 in the region of overlap $(-3$ to +3$)$ between normal and Down's syndrome populations (fig 2). Eight normal relatives had index

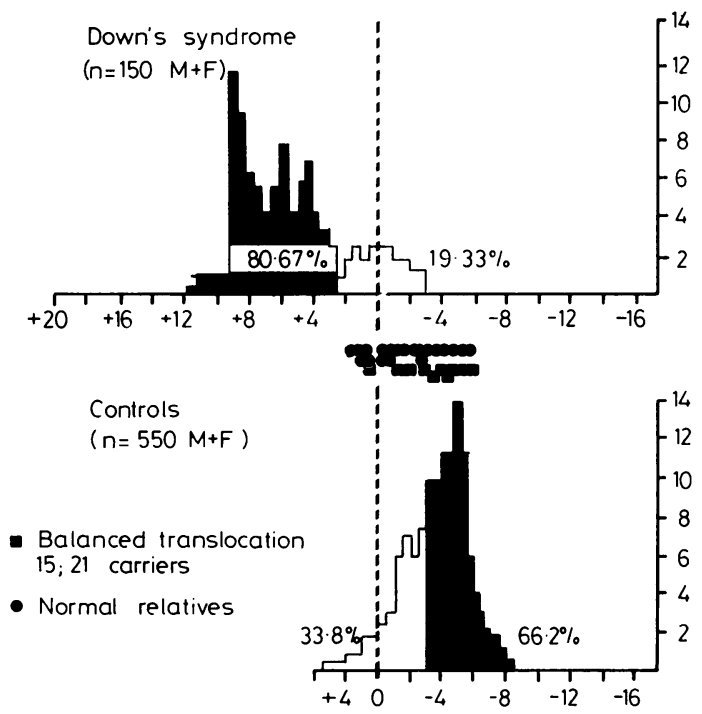

FIG 2 Histograms of the Walker indices based on digital, palmar, and plantar patterns.

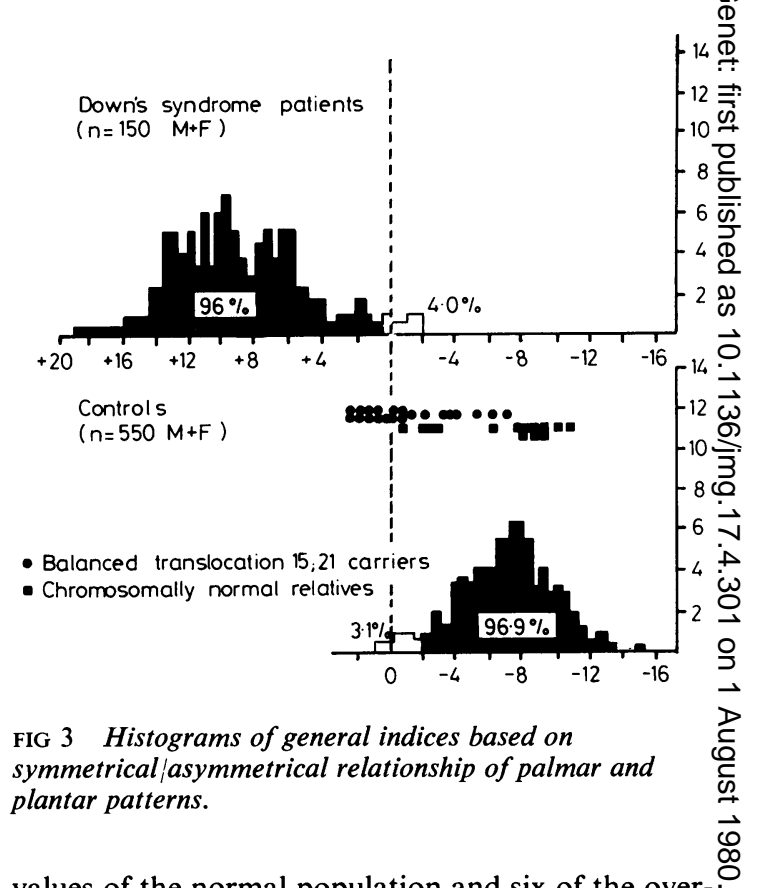

values of the normal population and six of the over-lap region. The values of the general index in theo balanced translocation carriers agreed better with those in Down's syndrome patients: eight carriers had values typical of Down's syndrome $(+0.5$ to $+19)$, six typical of the overlap region $(+0.5$ to -2$), \stackrel{\mathbb{Q}}{\varrho}$ and only seven typical of the normal population $(-2 \overrightarrow{\overrightarrow{0}}$ to -15 ) (fig 3). The data presented from this family 3 indicate that the state of having a balanced $15 ; 21 \supset$ translocation is often associated with distinctive combinations of dermatoglyphic patterns. Further investigations will be necessary to elucidate whetherọ translocations between other acrocentric chromo- somes (for example, 13;21 and 14;21) cause similar dermatoglyphic patterns in the balanced carriers.

The existence of special genes on chromosome $21, ₹$ which cause $\mathrm{t}^{\prime}$ or $\mathrm{t}^{\prime \prime}$ triradii, or both, in the case of a을 translocation, as postulated by Penrose and $>$ Delhanty, ${ }^{10}$ seems rather improbable, because the을 theoretical interpretation of the effect of such a N changed gene position is very difficult. Furthermore o the unusual combination of hypothenar patterns with $\tilde{O}_{0}$ $t^{\prime \prime}$ triradii is not present in all carriers of balanced N 13-15;21 translocation but can be found in almosto all other autosomal aberrations. The same feature can also be observed in $5 \%$ of normal subjects. ${ }^{8} \frac{\mathrm{C}}{\mathrm{D}}$ A more probable explanation for the increased $\stackrel{\text { O }}{?}$ occurrence of the dermatoglyphic peculiarities in 0 carriers of $13-15 ; 21$ translocations described here seems to be a general disturbance of regulatory $\overrightarrow{\mathbb{D}}$ mechanisms resulting from the loss of genes on the $\frac{\overrightarrow{\mathrm{D}}}{\square}$ 
fused acrocentric chromosomes. Similar effects are caused by other genetic derangements, especially chromosomal aberrations.

Since dermatoglyphic stigmata typical of Down's syndrome appeared in two-thirds of the 15;21 translocation carriers in this family, we suggest that dermatoglyphic examination might detect carriers in other 15;21 translocation families. Furthermore, we have some evidence that similar stigmata also appear in carriers of other translocations involving a chromosome 21 . We therefore feel that dermatoglyphic examination should be used to detect carriers of such balanced translocations in the normal population.

\section{References}

1 Walker NF. The use of dermal configurations in the diagnosis of mongolism. J Pediatr 1957;50:19-27.

2 Walker NF. The use of dermal configurations in the diagnosis of mongolism. Pediatr Clin North Am 1958;5: 531-8.

3 Beckman L, Gustavson KH, Norring A. Dermal configurations in the diagnosis of the Down syndrome: an attempt at a simplified scoring method. Acta Genet $1965 ; 15: 3-13$.

4 Reed TE, Borgaonkar DS, Conneally PM, Yu Pao-Lo W, Nance WE, Christian JC. Dermatoglyphic nomogram for the diagnosis of Down's syndrome. J Pediatr 1970;77: 6-17.

5 Borgaonkar DS, Davis M, Bolling DR, Herr HM. Evaluation of dermal patterns in Down's syndrome by predictive discrimination. I. Preliminary analysis based on frequencies of patterns. Johns Hopkins Med J 1971; 128:141-53.
${ }^{6}$ Bolling DR, Borgaonkar DS, Herr HM, Davis $M$. Evaluation of dermal pattern in Down's syndrome by predictive discrimination. II. Composite score based on the combination of left and right pattern areas. Clin Genet $1971 ; 2: 163-9$.

7 Deckers JFM, Oorthuys AMA, Doesburg WH. Dermatoglyphics in Down's syndrome. III. Proposal of a simplified scoring method. Clin Genet 1973;4:381-7.

8 Rodewald A. Das Hautleistensystem beim DownSyndrom mit einem Beitrag zur Differentialdiagnose. Disertation Thesis, Munich 1974:1-230.

9 Rodewald A, Zang KD, Ziegelmayer G. Bilateral symmetry of qualitative dermatoglyphic patterns in the Down's syndrome. $Z$ Morphol Anthropol 1976;67:333-44.

10 Penrose LS, Delhanty DA. Familial Langdon Down anomaly with chromosomal fusion. Ann Hum Genet $1961 ; 25: 243-52$.

11 Dallapiccola B, Ricci N. I dermatoglifi nella sindrome di Down tipica ed atipica. Acta Genet Med Gemellol (Roma) 1967;16/4:384-90.

12 Rosner F, Ong BH. Dermatoglyphic patterns in trisomic and translocation Down's syndrome (mongolism). Am J Med Sci 1967;253:556-62.

13 Walker NF, Carr DH, Sergovich FR, Barr ML, Soltan HC. Trisomy-21 and 13-15/21 translocation chromosome patterns in related mongol defectives. J Ment Defic Res $1963 ; 7: 150-63$

14 Fung A, Zavatone V. Dermatoglyphics in a family with 13-15/21 translocation. Cancer Bull 1969;21/5:94-5.

15 Sergovich FR, Hubert BA, Soltan C, Carr D. A 13-15/21 translocation chromosome in carrier father and mongol son. Can Med Assoc J 1962;87:852-8.

Requests for reprints to Professor A Rodewald, Institute of Human Genetics, University of Saarland, 6650 Homburg-Saar, Universitätskliniken Bau 68, Federal Republic of Western Germany. 